\title{
Synthesis of new functionalized thieno[2,3-b]pyridines
}

\author{
Darya Yu. Lukina1, Angela N. Stolyarova1, Victor V. Dotsenko',2* \\ ${ }^{1}$ Kuban State University, 149 Stavropolskaya str, Krasnodar, 350040 Russia \\ e-mail: victor_dotsenko@bigmir.net \\ ${ }^{2}$ ChemEx Lab, Vladimir Dal' Lugansk National University, 20A/7 Molodezhny, \\ Lugansk, 91034 Russia
}

\begin{abstract}
3-Aminothieno[2,3-b]pyridine-2-carboxamides react with chloroacetyl chloride to afford 3-(chloroacetylamino)thieno[2,3-b]pyridine-2carboxamides. The latter upon treatment with sodium azide gave 3(azidoacetylamino)thieno[2,3-b]pyridine-2-carboxamides. The reaction of 3(chloroacetylamino)thieno[2,3-b]pyridine-2-carboxamides with sulfur and amines afforded new monothiooxamides.
\end{abstract}

\section{Keywords}

thieno[2,3-b]pyridines, acylation, azides, monothiooxamides

Thienopyridines are important compounds because of their broad range of biological and pharmacological effects. Thieno[2,3-d]pyridines, for example, have been evaluated pharmacologically and used as potent and selective phosphodiesterase IV inhibitors, antipsychotics and anxiolytics, antiarrhythmics, antitumor agents, antibiotics, anti-inflammatory agents. Thus, the synthesis of thieno[2,3-b]pyridines as well as their ring condensed analogs is of interest.

In the present paper we report the synthesis of certain new thienopyridines modified by acylation of 3-amino group. Starting 3aminothieno[2,3-b]pyridine-2-carboxamides 1 were prepared by the known method [1] from 3-cyanopyridine-2(1H)-thiones 2 and 2-chloroacetanilides. First, we have prepared Guareschi-Thorpe 3-cyano-2-pyridones by reaction of 1,3-diketones with cyanoacetamide. The pyridones were converted to 2chloronicotinonitriles by treatment with $\mathrm{POCl}_{3}$ [1]. The prepared 2chloronicotinonitriles were reacted with thiourea to give 3-cyanopyridine- 
2(1H)-thiones 1 [2]. 4,6-Diaryl-3-cyanopyridine-2(1H)-thiones $\mathbf{3}$ were synthesized by reaction of malononitrile with chalcones, followed by the treatment of $\delta$-keto dinitrile formed with sulphur in the presence of an amine (morpholine or diethylamine)[3].

Starting 3-aminothieno[2,3-b]pyridine-2-carboxamides 1 were prepared in good yields by one-pot Thorpe-Ziegler cascade reaction of 3cyanopyridine-2(1H)-thiones $\mathbf{2}$ and $\mathbf{3}$ with $\alpha$-chloroacetanilides in boiling DMF in the presence of a strong base.


2, 3<smiles>[R]c1[nH]c(=S)c(C#N)c(C)c1[R]</smiles><smiles>[R]c1nc(SCC(=O)N[Al])c(C#N)c([R])c1[R]</smiles>

With 3-aminothieno[2,3-b]pyridine-2-carboxamides $\mathbf{1}$ in hands, we attempted to prepare 3-(chloroacetylamino) derivatives. We found that thienopyridines $\mathbf{1}$ easily react with chloroacetyl chloride in boiling dry toluene or benzene by known procedure [4] to give desired $\alpha$ chloroacetamides $\mathbf{4}$ as white or pale yellow solids.<smiles>[R]c1nc2sc(C(=O)N[Al-])c(N)c2c([R])c1[R]</smiles>

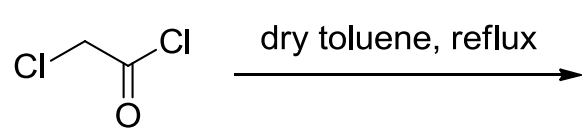<smiles>[R]c1nc2sc(C(=O)N[Al])c(NC(=O)CCl)c2c([R])c1[R]</smiles> 
Compounds 4 were found to be useful reagents in the synthesis of functionalized thieno[2,3-b]pyridines. Thus, when compounds 4 were reacted with sodium azide in DMF, azidoacetamides $\mathbf{5}$ were isolated in yields ranged from moderate to very good. The studies on the reactivity of the prepared azides are currently underway. Azides $\mathbf{5}$ are white solids, quite stable at ambient temperature.
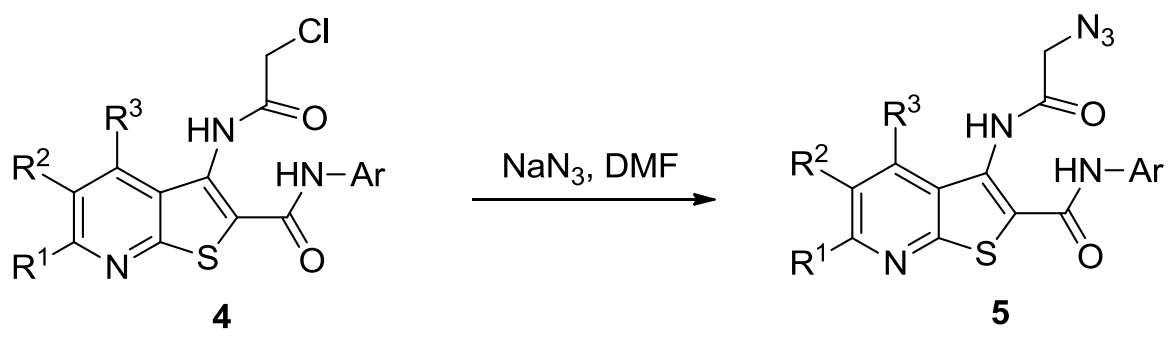

It is known that chloroacetamides react with sulphur and active amines to afford monothiooxamides [5, 6]. We found that the reaction of chloroacetamides 4 with morpholine and $S_{8}$ leads to the formation of thiomorpholides $\mathbf{6}$ in modest yields. The structure of products were confirmed by IR, NMR and LCMS data.
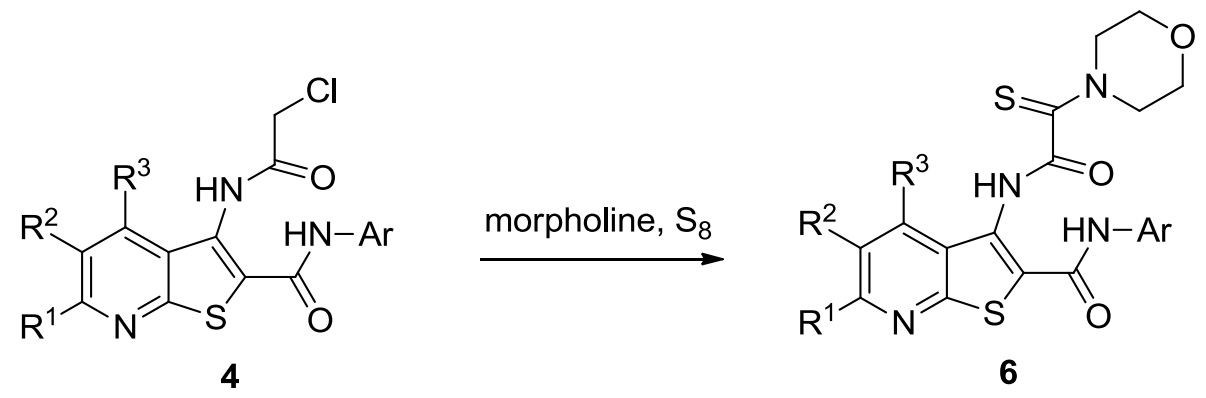

\section{References}

1. Kul'nevich V. G. et al. Synthesis and anti-viral activity of N-alkyl-3-cyano-2pyridones and 3-cyano-2-alkoxypyridines // Pharm. Chem. J. - 1990. - Vol. 24. - No 2. - pp. 132-135.

2. Guerrera F., Siracusa M. A., Tornetta B. Synthesis of 3-aminothieno-(2, 3-b) pyridine derivatives. II // Il Farmaco Ed.Sci. - 1976. - Vol. 31. - No 1. - pp. 2130.

3. A. M. Shestopalov, K. G. Nikishin, A. V. Gromova, and L. A. Rodinovskaya. One-pot synthesis of 4,6-diaryl-3-cyanopyridine-2(1H)-thiones and their transformation to substituted thieno[2,3-b;4,5-b]dipyridines and pyrido[3',2':4,5]thieno[3,2-d ]pyrimidines // Russ. Chem. Bull., Int. Ed. 2003. - Vol. 52. - No. 10. - Pp. 2203-2206. 
4. Kaigorodova E. A., Vasilin V. K., Osipova, A. A., Lipunov M. M., Krapivin, G. D. Synthesis of pentacyclic systems based on 3-amino-2-benzimidazol-2ylthieno[2,3-b]pyridines // Izvestiya Vysshikh Uchebnykh Zavedenii, Khimiya i Khimicheskaya Tekhnologiya (2004), 47(2), 107-114.

5. I. V. Zavarzin, V. N. Yarovenko, A. V. Shirokov, N. G. Smirnova, A. A. Es'kov and M. M. Krayushkin. Synthesis and reactivity of monothio-oxamides // ARKIVOC 2003 (xiii) 205-223

6. M. M. Krayushkin, V. N. Yarovenko, I. V. Zavarzin. Synthesis and reactivity of monothiooxamides and thiohydrazides of oxamic acids // Russ. Chem. Bull., Int. Ed. - 2004. - Vol. 53. - No. 3. - Pp. 517-527. 